\title{
Competence approach to teaching future primary school teachers
}

\section{Abordagem de competência para ensinar futuros professores do ensino fundamental}

\section{Enfoque por competencias para la enseñanza de futuros profesores de primaria}

\author{
Tetiana Vasiutina1 $^{(1 D}$, Olena Kondratiuk ${ }^{1}$ iD, Olga Lukianchenko1 $^{1}$, \\ Alla Romanchuk ${ }^{1}$ (D), Tetiana Teslenko ${ }^{1}$ (iD) \\ ${ }^{1}$ National Dragomanov Pedagogical University, Kyiv, Ukraine. \\ Corresponding author: \\ Tetiana Vasiutina \\ Email:npdu88@ukr.net \\ How to cite: Vasiutina, T., Kondratiuk, O., Lukianchenko, O., Romanchuk, A., \& Teslenko, T. (2022). Competence \\ approach to teaching future primary school teachers. Revista Tempos e Espaços em Educação, 15(34), e16598. \\ http://dx.doi.org/10.20952/revtee.v15i34.16598
}

\begin{abstract}
The article discusses the problems of forming the readiness of future primary school teachers for professional activity on the basis of a competence-based approach in the conditions of university complexes. Pedagogical experience shows that the educational process in a modern university already has many opportunities to solve problems that worry our specialists. However, these opportunities in universities are not yet fully used, as evidenced, in particular, by the contradictions that we examined in detail in this study. It is also noted that the training of a future teacher on the basis of a competency-based approach should provide for the formation of his professional competence through the gradual development, formation of its levels (key, basic, special) as a result of specialized training of the future teacher. Thus, the main purpose of the article is to study the process of implementing a competency-based approach in teaching future primary school teachers. For this, the methods of theoretical research of specialized literature were used, as a result of which the basic principles of the process of introducing and adapting the competence-based approach in teaching future primary school teachers were analyzed and systematized.
\end{abstract}

Keywords: Future primary school teachers. Pedagogy. Professional activity. Specialized training. Competency-based approach.

\section{RESUMO}

O artigo discute os problemas de formação da preparação dos futuros professores do ensino fundamental para a atividade profissional a partir de uma abordagem por competências nas condições dos complexos universitários. A experiência pedagógica mostra que o processo 
educacional em uma universidade moderna já oferece muitas oportunidades para resolver problemas que preocupam nossos especialistas. No entanto, essas oportunidades nas universidades ainda não são totalmente aproveitadas, como evidenciado, em particular, pelas contradições que examinamos em detalhes neste estudo. Salienta-se ainda que a formação de um futuro professor com base no enfoque de competências deve prever a formação da sua competência profissional através do desenvolvimento gradual, formação dos seus níveis (chave, básico, especial) a partir da especialização formação do futuro professor. Assim, o objetivo principal do artigo é estudar o processo de implementação de uma abordagem baseada em competências no ensino de futuros professores do ensino fundamental. Para tanto, foram utilizados os métodos de pesquisa teórica da literatura especializada, a partir dos quais foram analisados e sistematizados os princípios básicos do processo de introdução e adaptação da abordagem por competências no ensino de futuros professores do ensino fundamental.

Palavras-chave: Abordagem baseada na competência. Atividade profissional. Formação especializada. Futuros professores do ensino fundamental. Pedagogia.

\section{RESUMEN}

El artículo discute los problemas de formar la preparación de los futuros profesores de primaria para la actividad profesional sobre la base de un enfoque por competencias en las condiciones de los complejos universitarios. La experiencia pedagógica muestra que el proceso educativo en una universidad moderna ya tiene muchas oportunidades para resolver problemas que preocupan a nuestros especialistas. Sin embargo, estas oportunidades en las universidades aún no se aprovechan plenamente, como lo demuestran, en particular, las contradicciones que examinamos en detalle en este estudio. También se observa que la formación de un futuro docente sobre la base de un enfoque por competencias debe prever la formación de su competencia profesional a través del desarrollo paulatino, formación de sus niveles (clave, básico, especial) como resultado de la formación especializada. formación del futuro maestro. Por lo tanto, el objetivo principal del artículo es estudiar el proceso de implementación de un enfoque basado en competencias en la enseñanza de futuros maestros de educación primaria. Para ello, se utilizaron los métodos de investigación teórica de la literatura especializada, como resultado de lo cual se analizaron y sistematizaron los principios básicos del proceso de introducción y adecuación del enfoque por competencias en la docencia de los futuros docentes de primaria.

Palabras clave: Actividad profesional. Enfoque basado en competências. Formación especializada. Futuros maestros de primaria. Pedagogía.

\section{INTRODUCTION}

Deep socio-political, spiritual and economic shifts in the world are prompting the reform of the education system, which should provide conditions for the development and self-realization of each individual, the priority of universal human values, the formation of generations capable of learning throughout life, the creation and development of the values of civil society.

Competence is a systemic concept, the significant components of which are motives, goals, value orientations, knowledge, abilities, skills, reflection. Competence is a component of this system, the basis for the formation of competence, a structural and functional unit of competence. In the concept of "competence" such parties are distinguished as the ability and readiness for effective activity. It is believed that competence is mastered by a person in the educational process, and competence is formed in the process of this development. Within the framework of this approach, design education must be considered as a special quality and type of education, as a result of which the upbringing of a project-thinking person takes place, in whatever area of social practice he or she acts - spiritual culture, production, science (including practice), household sphere, etc. 
The essence of the training of designers is the development of creative abilities and abilities of reflective reflection of the world as the basis for the design and artistic formation of the sociocultural environment. Creativity is a productive activity, that is, it has a goal and is aimed at a result, in contrast to reproductive activity, the purpose of which is the mechanical repetition of the known. The difference between creative (productive) and reproductive activity is the difference between solving a problem without an algorithm and solving a problem using a specific rule. In psychology, most researchers understand creativity as a certain set of mental and personal characteristics.

So K. Longman lists the following characteristics as "common for highly creative people": curiosity or curiosity, vivid imagination, the ability to empathy, flexibility.

It is not limited to any one side, but exists as a synthesis of the cognitive, emotional and volitional spheres of human consciousness. Creativity is closely related to personality traits (character, abilities, interests, etc.). A special place in the creative process is occupied by imagination, which must be provided with knowledge, supported by abilities, purposefulness and accompanied by an emotional tone. All this totality of mental activity can lead to discoveries, inventions, the creation of various values in all types of human activity. " (Alves \& Souza, 2018; Cordeiro et. al., 2021; Falcão \& Silva, 2020).

Creative thinking, as defined by the American psychologists G. Lindsay and K. Thompson, is thinking aimed at discovering a fundamentally new or improved solution to a particular problem. Creative thinking is aimed at creating new ideas; therefore, a person learns to give his thoughts complete freedom and not try to direct them along a certain channel. According to American psychologists, there are five barriers to the development of creative thinking:

- conformism - fear of expressing unusual, creative ideas. The opposite trait of conformism is the propensity to take risks or a perceived right to error. A creative person always brings a certain risk into his activity, knowing that sooner or later it will definitely pay off.

As Oscar Wilde said, an idea without danger can hardly be called an idea at all:

- internal and external censorship. If people are afraid of their own ideas, they tend to react passively to their surroundings and do not even try to creatively solve problems that arise;

- rigidity - lack of mobility, switchability, adaptability of thinking in relation to the changing requirements of the environment;

Only a teacher with pronounced creative abilities, capable of organizing his work at an innovative level, can solve these problems, so now the problem of preparing future teachers for innovative activities is of great pedagogical and social significance. Modern trends in the development of higher professional education necessitate the training of a competitive, professionally competent specialist. which meets the modern requirements of society. Modernization of higher education in Ukraine, in particular, the harmonization of higher education in accordance with the main provisions of the Bologna Declaration, identified an important problem of reforming the system of training primary education specialists - improving the quality of education, forming the readiness of university graduates for further activities and life in society.

The solution of the set tasks is associated with the introduction of a competence-based learning model in universities. The problem of teacher professional training has always been given due attention both at the state and at the scientific and methodological level.

The process of socio-economic changes in society has become the reason for the revision of educational policy both in general and its individual components, in particular, the strategy for training future specialists. The modernization of the educational system raises new questions about the level of knowledge and skills of specialists in the field of primary education. The most important task of modern higher education is the preparation of a competent, flexible and competitive specialist who is able to achieve a certain goal in various life situations. Pedagogical experience testifies that the educational process in the conditions of a modern university already has many opportunities for solving problems that worry our specialists. 
However, these opportunities in universities are not yet used in full, as evidenced, in particular, by the contradictions: between the objective needs of society for professional competence specialists in the field of primary education, the unique requirements for their activities, a measure of scientific development of problems of formation of professional competence; a unique stable the system of training primary school specialists and the personalityoriented nature of their work with various objects; awareness by future specialists of the need and importance of developing professional competence and insufficient experience and the level of formation of their practical skills in the field of primary education.

The elimination of these contradictions requires a rethinking of approaches to the professional training of modern specialists in the field of primary education. The competence approach becomes an important component in the professional training of the future specialist in primary school. One of the most important features of higher education is the growing importance of the competence of a future specialist.

Today it is important to be not only qualified, but above all a competent specialist. Competence helps a specialist to effectively solve a variety of tasks that relate to his professional activities. A competent specialist is distinguished by a qualified specialist in that he implements professional knowledge, skills and abilities in his work; is always engaged in self-development and goes beyond the limits of his discipline; considers his profession to be of great value. The world community makes its demands on future specialists. First, the specialist must have knowledge of modern scientific, pedagogical, social and political problems; have the ability to apply natural science, mathematical, social and humanitarian knowledge in practice; formulate and solve various pedagogical problems and tasks; design processes or systems in accordance with the tasks. Secondly, the future specialist must effectively interact with the team, be able to apply skills and learned methods in scientific and pedagogical practice, and have professional and ethical responsibility (Kovshar et. al., 2019; Lacerda \& Marques, 2021; Mushynska, 2018).

Due to the fact that employers focus on the presence of systemic, intellectual, communicative qualities in graduates of higher educational institutions, the ability to self-organize and organize the activities of employees, the ability to reflect on their own activities, society's requirements for the professional training of primary school specialists are constantly growing. Taking this into account, the main goal of higher education is to train a qualified specialist who is competitive in the labor market, competent, fluent in the profession and navigates in related fields of activity, ready for continuous professional growth, social and professional mobility.

The problem of forming the professional competence of future specialists in the process of studying at a university attracts the attention of many scientists. The interest of scientists in the aspects of the formation of professional competence is due to the transition of the world community to the information society, where the priority is not just the accumulation of knowledge, skills and abilities by future primary school specialists, the formation of the ability to learn, the mastery of information search skills, the ability to self-study throughout life.

Most researchers note that the task of modern higher education is not only to provide professional knowledge, but also to prepare a specialist who deeply understands and knows his role in society, is able to creatively use the knowledge gained in practice, and also knows how to work with children in a collective.

\section{METHODOLOGY}

The main purpose of the study is to determine the process of implementing a competencybased approach in teaching future primary school teachers. For this, a number of methods were applied, which form the research methodology. The study was carried out using the following theoretical methods: systems analysis and synthesis, induction and deduction, comparison, classification, generalization and systematization, idealization and abstraction. 


\section{RESULTS AND DISCUSSION}

The competence-based approach also has pedagogical prerequisites, both in practice and in theory. The level of training of graduates largely depends on some additional qualities, for which the concepts of "competence" and "competence" are used, which are more consistent with the understanding of modern goals of education and are the basic categories: competence-based approach, competence, professional, education, specialty.

Professional education focused on the formation of graduates' competencies is not a tribute to fashion, but an objective phenomenon in education, brought about by socio-economic, political, educational and pedagogical prerequisites.

First of all, it is the reaction of vocational education to the changed socio-economic conditions, to the processes resulting from the market economy. Currently, the sphere of work and the sphere of personnel training for this labor sphere have diverged far in different directions. In the last decade and a half, radical changes have taken place in the content of all professions. $A$ number of professions turned out to be unclaimed, at the same time, many new professions arose.

The changes are due to the following reasons: reorientation of demand for new skills and changes in the organization of work; falling demand for unskilled manual labor; the spread of automated production process control systems; - a decline in mass production; increasing the individual responsibility of employees for the quality of work; the growing need for direct communication of employees with clients and customers; increasing the level of interaction between employees in the team; blurring the boundaries between professions, etc.

All this requires a significant increase in the degree of flexibility of vocational education, but not just its one-time reorientation from "dead" professions to "new" ones, but the creation of fundamentally new mechanisms that ensure its constant adjustment to the dynamically changing requirements of the labor market.

The crisis in the vocational education system is caused by a number of factors. There are especially significant ones: increased demand for the quality of higher professional education; constantly changing living conditions; the need to form professional thinking, activity, responsibility, sustainable professional motivation of future specialists to ensure their readiness for professional mobility and social adaptability; the inertia and conservatism of the sphere of vocational education, its inadaptation to socio-cultural dynamics; ineffectiveness of pedagogical work; poor development of vocational training technologies.

These circumstances indicate that there is a gap in the training of specialists, which consists in the fact that when forming a system of subject knowledge and skills, educational institutions are paying clearly insufficient attention to the development of many personal and social competencies that determine (at the same level of education) the competitiveness of a graduate. The modernization of education requires the preparation of a new generation of researchers, highly qualified specialists capable of carrying out innovative activities in a market economy.

Competence cannot be determined through a certain amount of knowledge and skills, since circumstances play a significant role in its manifestation. To be competent means to mobilize the acquired knowledge and experience in a given situation. It is competence that allows an individual to navigate unforeseen social situations, which means the success of socialization. Socialization is the process of interaction between a person and the social environment. A person not only assimilates social experience, but transforms it into his values, attitudes, and orientations. The result of socialization is socialization, that is, the formation of traits given by the status and required by a given society.

Thus, the competence-based approach allows:

- align the learning goals set by the educators with the learners' own goals. With each new generation of students, the significance of this moment increases, for each new generation of 
schoolchildren is becoming more independent, more independent of the views and judgments of adults, capable of setting their own goals in life;

- to increase the degree of motivation for learning, first of all, due to the awareness of its benefits for the present and future life of students;

- to facilitate the work of the teacher by gradually increasing the degree of independence and responsibility of students in learning. The "rickshaw teacher" who pulls the entire educational process on himself must turn into a "train driver" who only manages the learning process. Moreover: at a certain stage, the students themselves become assistants and employees of the teacher in teaching;

- to unload students not by mechanical reduction of content, but by increasing the share of individual self-education, shifting attention to ways of working with information, group distribution of loads and changes in motivation;

- not in theory, but in practice, to ensure the unity of educational and educational processes, when the same tasks of versatile preparation for life are solved by different means of lesson and extracurricular activities, without any special "educational measures" or special "educational lessons", and the student understands the importance of his own upbringing and his own culture for his life.

The general idea of the competence-based approach is competence-oriented education, which is aimed at the integrated assimilation of knowledge and methods of practical activity, thanks to which a person successfully realizes himself in various areas of his life. The concept of "approach" in a general sense means a certain set of various means and techniques that act in a certain way on someone. In the scientific sense, the concept of "approach" is interpreted as the starting point, which is the basis of research activities (Oliveira et. al., 2021; Onyshkiv et. al., 2021).

This approach orients a person towards constant professional and personal selfimprovement, independent search for new knowledge, independent development of the necessary skills and abilities. The competence-based approach shifts the emphasis from the process of accumulating normatively defined knowledge, skills and abilities to the plane of the formation and development of the ability of future specialists to practically act and creatively apply the knowledge and experience gained in various situations. This requires the teacher to shift the emphasis in his teaching and educational activities from the informational to the organizational and managerial plane (Vargas et. al., 2020).

In the first case, he played the role of a relay of knowledge, and in the second, an organizer of educational activities. The behavior model of the future specialist is also changing - from passive assimilation of knowledge to research-active, independent and self-educational activity. The process is filled with a developmental function, which becomes an integrated characteristic of learning. Such a characteristic is formed in the learning process and includes knowledge, abilities, skills, attitudes, experience and behavioral models of the individual. At the same time, new requirements for teaching aids appear in the system of the competence-based approach to teaching in higher education. It is advisable to give preference to those of them that contain communicativesituational tasks, tasks requiring the involvement of the experience of future specialists, close to life, future professional activities, stimulate their active thinking. A competency-based approach to professional training should cover, along with specific knowledge and skills of future specialists, their abilities, readiness for knowledge, for professional activity, social skills, etc.

One of the main tasks of higher education, together with the formation of a harmoniously developed personality, is the task of forming a professionally competent specialist who has a number of key competencies. The word "competence" in Latin means a range of issues in which a person is well aware, in relation to which he possesses knowledge and experience. Now in the literature there are various definitions of the concept of "competence" from an educational point 
of view. For example, competence is a general ability based on knowledge, experience, values, inclinations that are acquired through training.

Competence is a social requirement (norm) for the educational preparation of a student, necessary for his high-quality productive activity in a particular area. Considering educational competence, A. Khutorskoy gives the following definition: "Educational competence is a requirement for educational preparation, expressed by a set of interconnected semantic orientations of knowledge, skills, skills and experience of a student's activity in relation to a certain range of objects of reality, necessary for a person to be socially significant productive activity " (Palshkova et. al., 2021).

The most general idea of the concept of "competence" is the ability to solve complex problems. Among many definitions, one can find common elements that reveal the categorical essence of this concept. Note that some definitions of competence are focused on external influences, others on internal characteristics, but common to all definitions is the understanding of competence as the ability of a person to solve various problems, as a set of knowledge, skills and abilities necessary for the implementation of specific activities. Of particular importance is the ability to act in non-standard, new conditions. Therefore, competence must be considered as a result of learning, expressed in the ability to apply knowledge, skills and personal qualities for successful activities. Scientists define the following groups of key competencies: value-based; general cultural; educational cognitive; -informational; communicative; social and labor; personal self-improvement.

Based on this, a person competent in a certain area is a person who has the appropriate knowledge and abilities that allow him to reasonably speak about this industry and act effectively in it. Professional training of a future primary school teacher in the context of a competency-based approach should be based on the following principles:

1. The principle of humanism - creating conditions for the formation of the best qualities and abilities of the student; humanization of relations between teachers and pupils, respect for the personality of a future specialist, understanding of requests, interests, dignity, education of a humane personality, sincere, humane, benevolent, merciful.

2. The principle of democratization - elimination of the authoritarian style in communication. The perception of the personality of the future teacher as the highest social value, the definition of his right to freedom, the development of pedagogical abilities.

3. The principle of competence - creating conditions for the development of the necessary structural elements of the graduate's pedagogical competence.

4. The principle of pedagogical creativity - creating conditions for the development of individually personal creativity.

5. The principle of problematicity presupposes the orientation of the future specialist towards solving real pedagogical problems.

6. The principle of realism presupposes the orientation of a graduate of a pedagogical institution towards achieving real pedagogical goals, mastering the means and methods necessary for this.

7. The principle of pedagogical self-development assumes the orientation of the graduate to create conditions for the stable satisfaction of his own spiritual and pedagogical needs in selfdevelopment and self-realization. Professional training of future teachers will be effective if it is carried out in a complex of the specified approaches and principles and has a holistic character.

8. The principle of personality orientation - the choice of the content of methods, forms of teaching is based on the natural inclination of students to learn, purposefully actualizes their spiritual needs and interests, contributes to spiritual self-realization.

9. The principle of technological unity of the learning process, the use of new learning technologies. 
10. The principle of dialogization of teaching is the rejection of monologism as a socially oriented communication of dialogue, the development of students' ability to see the strong and weak aspects of the interlocutor, critically treat the information received, distinguish between biased and impartial information, identify differences in the positions of the participants in the dialogue and understand the position of the interlocutor.

The purpose of the professional training of a future primary school teacher is to ensure his competitiveness in the market of educational services. The main tasks of forming the professional competence of a future specialist in primary education are:

- to create conditions for the formation of the professional culture of the future specialist;

-activate the formation of key competencies of the future primary school teacher;

- to ensure mastery of technologies of self-organization and self-actualization;

- to form the professional mobility of students;

- to organize methodological, didactic support of students; to form social activity based on personal qualities and social skills of the individual.

The effectiveness of the process of professional training of a future primary school teacher in the context of a competence-based approach in the system of stepwise training will depend on the completeness of the implementation of all its components.

Specific ways can be: adjusting and coordinating the content of education, curricula and training programs for specialists, teaching aids, textbooks, teaching materials, developing research programs; holding scientific and theoretical conferences and seminars, practically methodological meetings on topical problems of forming the professional competence of future teachers primary classes; creation on the basis of the best educational institutions of experimental centers, laboratories for processing educational innovations, dissemination of advanced experience of teaching staff; development and implementation of new courses that contribute to the formation of professional and pedagogical competence of future primary school teachers; development and implementation of new teaching and education methods with the goal of forming a competitive educator; using the media to highlight the best pedagogical experience; studying the world teaching experience, adaptation of the best examples of the formation of professional competence; establishing contacts with international organizations, holding joint international events and projects; effective use of innovative educational technologies. Training of a future teacher based on a competence-based approach should provide for the formation of his professional competence through the gradual development, formation and formation of it levels (key, basic, special) as a result of specialized training of the future teacher (Passone, 2019; Savchenko, 2018).

The main levels of professional competence of the subject of activity are the result of training, professional preparedness, professional experience and professionalism. In order to become a competent specialist, a future teacher during his professional training at a university needs to develop key competencies as the most universal in nature and corresponding to a wide range of activities. In connection with the active introduction of ICT in the educational process, information competence plays an important role in the professional training of a future teacher.

Note that the formation of the professional competence of a future specialist is carried out through the content of education, it includes not only a list of academic subjects, but also professional skills and abilities that are formed in the process of mastering the subject, as well as the means of the student's active position in the social, political and cultural life of the university. All this together forms and develops the personality of the future teacher, his ability to selfdevelopment and self-improvement, which will allow him to ensure effective functioning as a professional subject in the "person-person" system. We refer to the main conditions for the development of students' professional competence: 
1. Organizational and managerial (curriculum, semester schedules, scheduling, development of criteria for determining the level of competence, material and technical equipment of the educational process).

2. Scientific-methodological (selection of the content of classes, integration of various courses, highlighting the leading ideas).

3. Technological (control and evaluation, the organization of active forms of education, the definition of groups of skills included in the competence, the use of innovative technologies).

4. Psychological and pedagogical (diagnostics of students' development, a system of stimulating motivation for learning, determining criteria for competence, evaluative reflection of the stages of each lesson, including students in management). The competence approach makes special requirements to the structure of educational and methodological support of the educational process.

\section{CONCLUSION}

The growing role of the educational process in the development of a personality, its ability to control itself, independently master new information necessitate a revision of ideas about the forms, methods and conditions of education, respectively, lead to the modernization of the educational process and the training of future specialists. So, one of the main tasks of modernizing the educational process at the university is the search and implementation of such educational technologies, methods and means that contribute to the enrichment of the motivation of educational activities, the development of the readiness of future teachers to carry out professional activities, independence, the manifestation of creative individuality and full self-realization. Due to the fact that the development of the information society, the informatization of education is currently being carried out at a rapid pace, professional training should be continuous.

Authors' Contributions: Vasiutina, T.: conception and design, acquisition of data, analysis and interpretation of data, drafting the article, critical review of important intellectual content; Kondratiuk, O.: conception and design, acquisition of data, analysis and interpretation of data, drafting the article, critical review of important intellectual content; Lukianchenko, O.: conception and design, acquisition of data, analysis and interpretation of data, drafting the article, critical review of important intellectual content. Romanchuk, A.: conception and design, acquisition of data, analysis and interpretation of data, drafting the article, critical review of important intellectual content; Teslenko, T.: conception and design, acquisition of data, analysis and interpretation of data, drafting the article, critical review of important intellectual content. All authors have read and approved the final version of the manuscript.

Ethics Approval: Not applicable.

Acknowledgments: Not applicable.

\section{REFERENCES}

Alves, A. V. V. ., \& Souza, A. D. de . (2018). Literacy in school democratic management : some notes. Laplage in Journal, 4(2), 114-122.

Cordeiro, E. de P. B., Marques, M. M. C., \& Costa, M. T. N. (2021). Socio-emotional education: paths to inspire studies, research and practices. Revista Tempos e Espaços em Educação, 14(33), e13729.

https://doi.org/10.20952/revtee.v14i33.13729

Falcão, N. M., \& Silva, S. dos S. da. (2020). Student's participation in upper secondary school management: approaches to the reality of the school system in the state of Amazonas . Revista Tempos e Espaços em Educação, 13(32), 1-19. https://doi.org/10.20952/revtee.v13i32.13168

Kovshar, E., Palshkova, I., Savchenko, L. (2019). Interaction of Productive and Interactive Technologies in the Educational Process of School. Amazonia Investiga, 8(20), 229-235.

Lacerda, R. P. de, \& Marques, R. N. (2021). My school is my nation project: paths for the construction of school identity. Revista Tempos e Espaços em Educação, 14(33), e16475. https://doi.org/10.20952/revtee.v14i33.16475 
Mushynska, N. (2018). Means of future economists' professional self-development in the educational process of foreign language studying. Economics, Ecology, Socium, 2(3), 45-56

Oliveira, M. A. C. ., Nichio, E. R. ., Santos, G. S. do N. ., Andrade, F. S. de ., \& Pacífico, J. M. . (2021). Challenges and reflections on cultural diversity in the context of the pandemic COVID-19. Laplage in Journal, 7(Extra-A), p.224-232. https://doi.org/10.24115/S2446-622020217Extra-A753

Onyshkiv, Z., Kodliuk, Y., Lesina, T., Malyna, O., \& Kichuk, N. (2021). Areas of modernization of preparation of future elementary school teachers in the countries of the European community. Revista Tempos e Espaços em Educação, 14(33), e15615. https://doi.org/10.20952/revtee.v14i33.15615

Palshkova, I. O., Balakirieva, V. A., Skoromna, M. V., \& Shpaliarenko, Y. A. (2021). Analysis of the problem on preparing future primary school teachers for the organization of pupils' labor training. Revista Tempos e Espaços em Educação, 14(33), e16091. https://doi.org/10.20952/revtee.v14i33.16091

Passone, E. F. K. . (2019). School management and democracy:: what school efficiency studies teach us. Laplage in Journal, 5(2), 142-156.

Savchenko, L. (2018). Functional role of monitoring in assessing the quality of future handicraft teacher training. Science and education, 2, 186-192. https://doi.org/10.24195/2414-4665-2018-2-25

Vargas, T. C., Bizelli, J. L., \& Santos Cruz, J. A. (2020). Quality in education: what's the suitable funding to the basic education?. Revista Tempos e Espaços em Educação, 13(32), 1-17. https://doi.org/10.20952/revtee.v13i32.13625

Received: 11 October 2021 | Accepted: 12 December 2021 | Published: 18 January 2022

This is an Open Access article distributed under the terms of the Creative Commons Attribution License, which permits unrestricted use, distribution, and reproduction in any medium, provided the original work is properly cited. 